\title{
Sistem Informasi Geografis Objek Wisata Kabupaten Lombok Barat Berbasis Web
}

\author{
${ }^{1}$ Subhan, ${ }^{2}$ Rusydi Umar \\ 1,2 Program Studi Teknik Informatika Universitas Ahmad Dahlan Prof. Dr. Soepomo, S.H., Janturan, Umbulharjo, \\ Yogyakarta 55164

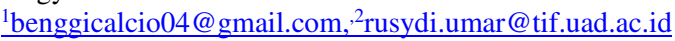

\begin{abstract}
Abstrak
Penelitian ini meneliti tentang objek wisata yang berada di Kabupaten Lombok Barat. Sistem diharapkan dapat menampilkan gambaran tempat objek wisata di Kabupaten Lombok Barat sehingga proses pencarian lebih cepat. Subjek pada penelitian ini mengkaji tentang SIG berbasis web. Objek penelitian yaitu lokasi objek wisata.

Metode pengumpulan data dilakukan dengan menggunakan metode observasi, metode wawancara, dan metode studi pustaka. Metode observasi yaitu pengumpulan data dengan cara langsung mengamati permasalahan mengenai objek wisata di Kabupaten Lombok Barat. Metode wawancara dengan melakukan tanya jawab kepada orang yang mempunyai kapasitas dan informasi yang dibutuhkan dalam pelaksanan penelitian. Metode studi pustaka dengan melakukan pengumpulan data literatur yang berhubungan dengan subjek penelitian tentang SIG, baik dari artikel, penelitian terdahulu maupun dari website, serta mempelajari dan menganalisa literatur yang berhubungan dengan informasi objek wisata.

Hasil dari penelitian ini adalah sebuah sistem informasi geografis yang dapat memberikan kemudahan bagi masyarakat maupun wisatawan lokal dan asing, tentang informasi jarak, lokasi, deskripsi dan foto objek wisata yang berada di Kabupaten Lombok Barat. Hasil dari pengujian sistem menunjukkan bahwa sistem informasi geografis ini layak dan dapat dipergunakan dengan hasil pengujian sistem menggunakan metode Alpha Test yang ditujukan kepada masyarakat, pegawai dinas kebudayaan dan pariwisata Kabupaten Lombok Barat menunjukkan persentase sangat setuju mencapai 52,38\% dan setuju mencapai 47,62\%. Black Box Test ditujukan kepada Muhammad Zikri, S.S. Selaku Staff Dinas Kebudyaan dan Pariwisata Kabupaten Lombok Barat dengan hasil 100\% setuju.
\end{abstract}

Kata Kunci : Codeigniter, Objek Wisata, Web, Kabupaten Lombok Barat.

\section{Pendahuluan}

Informasi merupakan kebutuhan yang sangat penting bagi setiap orang. Informasi dapat memberikan gambaran secara jelas mengenai suatu hal dari sudut pandang yang berbeda. Dengan demikian, informasi dapat dikatakan salah satu faktor yang sangat penting untuk mengambil keputusan selanjutnya. Sistem informasi geografis sangat dibutuhkan untuk mengelola informasi mengenai tempat parwisata yang akan disajikan secara online dan dapat di akses dengan lebih informative, dimana di dalamnya terdapat gambar yang menginformasikan tentang objek wisata tersebut.

Kabupaten Lombok Barat merupakan salah satu daerah andalan sektor pariwisata di Pulau Lombok yang mempunyai banyak tempat-tempat objek wisata, yang terus membangun dan memunculkan obyek wisata baru yang belum banyak dikenal oleh masyarakat luas. Hal ini digunakan untuk mendukung rencana pengembangan Kabupaten Lombok Barat. Jumlah wisatawan yang datang ke Kabupaten Lombok Barat dari tahun ke tahun semakin bertambah. Ini menunjukkan bahwa objek wisata di Kabupaten Lombok Barat semakin diminati wisatawan. Salah satu obyek wisata yang menjadi primadona wisatawan di Kabupaten Lombok Barat adalah obyek wisata Pantai Senggigi. Karena air laut Pantai Senggigi begitu jernih dan bersih, bahkan kita dapat melihat langsung kawanan ikan yang berenang dengan bebasnya di laut Senggigi. 
Pemerintah Kabupaten Lombok Barat telah melakukan promosi melalui media masa seperti surat kabar dan pamflet. Namun metode tersebut belum cukup untuk menginformasikan kepariwisataan secara meluas kepada wisatawan lokal maupun asing. Para wisatawan akan mengalami kesulitan untuk menentukan perencanaan perjalanan wisata karena gambaran daerah wisata tersebut tidak tersedia sepeti visualisasi tempat, jarak antar daerah wisata serta jalan yang akan dilalui. Oleh karena itu melalui perancangan dan pembuatan sistem informasi geografis objek wisata diharapkan dapat menampilkan gambaran peta wisata Kabupaten Lombok Barat sehingga lebih menarik dan dapat dinikmati oleh masyarakat luas. Penyajian informasi dalam bentuk web akan memudahkan masyarakat untuk mengaksesnya.

\section{Kajian Pustaka}

Penelitian dan perancangan Sistem Informasi Geografis mengenai objek wisata di suatu daerah, sebelumnya pernah dilakukan oleh beberapa mahasiswa. Penelitian sebelumnya pernah dilakukan oleh Yolan pada tahun 2015 dari Universitas Borobudur Jakarta dengan judul "Sistem informasi Pariwisata Provinsi Nangroe Aceh Darussalam Berbasis Web". Sistem yang telah dibangun tersebut menggunakan bahasa pemrograman PHP dan MySQL dan mampu untuk memberikan fasilitas pencarian objek wisata, rumah makan, agent travel. Namun dalam sistem tersebut belum mampu memberikan fasilitas untuk wisatawan mengenai rute dan jarak yang harus ditempuh [1].

Sistem Informasi Geografis (SIG) berbasis web untuk pemetaan pariwisata kabupaten kebumen, oleh Puput lestri, 2013. Aplikasi yang dibuat yaitu mengenai sebaran lokasi pariwisata yang ada beserta sarana dan prasarana dari pariwisata itu sendiri. Informasi yang ditampilkan yaitu objek wisata, namun tidak menyediakan informasi mengenai keadaan iklim lokasi wisata [2].

Penelitian selanjutnya dilakukan oleh Fajrizal, Teknik Informatika Universitas Lancang tahun 2015 dengan judul Sistem Informasi Geografis Berbasis Web untuk Pemetaan Kelurahan Sei. Mempura (Studi Kasus Pada Dinas Pariwisata Kelurahann Sei.Mempura). Sistem ini menggunakan bahasa pemrograman PHP dan MySQL sebagai database, dan ArcView 3.3 sebagai editor peta. Aplikasi yang dihasilkan berupa sistem informasi geografis berbasis web untuk pemetaan pariwisata Kelurahan Sei. Mempura, yang didigitasi menggunakan ArcView [3].

\subsection{Sistem Informasi}

Sistem dapat didefinisikan sebagai kumpulan ide, objek, berikut saling berhubungan (inter-relasi) dalam mencapai tujuan atau sasaran bersama [4].

\section{Sistem Informasi Geografis (SIG)}

Sistem Informasi Geografis (SIG) adalah suatu sistem informasi yang digunakan untuk memasukkan, menyimpan, memanggil kembali, mengolah, menganalisa, dan menghasilkan data yang mempunyai referensi geografis atau lazim disebut data geospatial, yang berfungsi sebagai pendukung pengambilan keputusan dalam perencanaan dan pengelolaan penggunaan lahan, sumber daya alam, lingkungan, transportasi, fasilitas kota, dan pelayanan umum lainya.

\section{Kemampuan SIG}

Adapun kemampuan dari Sistem Informasi Geografi adalah sebagai berikut:

a. Memasukkan dan mengumpulkan data geografi.

b. Mengintegrasikan data geografi.

c. Memeriksa, meng-update (mengedit) data geografi.

d. Menyimpan dan memanggil kembali data geografi.

e. Mempresentasikan atau menampilkan data geografi.

f. Mengelola, Memanipulasi dan Menganalisa data geografi.

Contoh: 
1) Mengelola meliputioperasi menambah, mengedit dan mendelete datadata yang ada dalam sistem.

2) Memanipulasi meliputimengelola data yang ada di lapangan, kemudian didigitasi ke dalam Peta yang bisa diakses secara online.

3) Menganalisa meliputimenganalisa data-data yang ada di lapangan kemudian menampilkan jumlah data-data tersebut melalui grafikgrafik di dalam sistem.

4) Menghasilkan keluaran (output) data geografi dalam bentuk yang meliputi peta tematik (view \& layout), tabel, grafik, laporan (report) dan lainnya baik dalam bentuk hardcopy maupun soft copy.

\section{Fungsi-fungsi SIG}

Berdasarkan desain awalnya fungsi utama SIG adalah untuk melakukan analisis data spasial. Dilihat dari sudut pemrosesan data geografik, SIG bukanlah penemuan baru. Pemrosesan data geografik sudah lama dilakukan oleh berbagai macam bidang ilmu, yang membedakannya dengan pemrosesan lama hanyalah digunakannya data digital. Adapun fungsi -fungsi dasar dalam SIG adalah sebagai berikut Aini (2007).

a. Akuisisi data dan proses awal meliputi digitasi, editing, pembangunan topologi, konversi format data, pemberian atribut.

b. Pengelolaandatabase meliputi pengarsipan data, permodelan bertingkat, pemodelan jaringan pencarian atribut.

c. Pengukuran keruangan dan analisis meliputi operasi pengukuran jarak tempuh, dan waktu tempuh

d. Penayangan grafis dan visualisasi meliputi transformasi skala,generalisasi, peta topografi, peta statistik, tampilan perspektif.

\section{Cara Kerja SIG}

SIG dapat menyajikan real world (dunia nyata) pada monitor sebagaimana lembaran peta dapat merepresentasikan dunia nyata di atas kertas. Tetapi, SIG memiliki kekuatan lebih dan fleksibilitas dari pada lembaran pada kertas. Peta merupakan representasi grafis dari dunia nyata, obyek-obyek yang dipresentasikan di atas peta disebut unsur peta atau mapfeatures (contohnya adalah sungai, taman, kebun, jalan dan lain-lain). Karena peta mengorganisasikan unsur-unsur berdasrkan lokasilokasinya. SIG menyimpan semua informasi deksriptif unsur-unsurnya sebagai atributatribut didalam basisdata. Kemudian, SIG membentuk dan menyimpannya didalam tabel-tabel (relasional) dengan demikian, atribut-atribut ini dapat di akses melalui lokasi-lokasi unsur-unsur peta dan sebaliknya, unsur-unsur peta juga dapat di akses melalui atribut-atributnya [5].

\section{Sub Sistem Informasi Geografis}

SIG dibagi menjadi empat subsistem, yaitu:

\section{a. Data Input}

Subsistem ini bertugas untuk mengumpulkan dan mempersiapkan data spasial dan atribut dari berbagai sumber. Sub sistem ini pula yang bertanggung jawab dalam mengkonversi atau mentransformasikan format-format data aslinya ke dalam format yang digunakan oleh SIG.

\section{b. Data Output}

Subsistem ini menampilkan atau menghasilkan keluaran seluruh atau sebagian basis data baik dalam bentuk softcopy maupun bentuk hardcopy seperti tabel, grafik, peta, dan lain-lain.

\section{c. Data Management}

Subsistem ini mengorganisasikan data spasial maupun atribut ke dalam sebuah basis data sedemikian rupa sehingga mudah dipanggil, di-update, dan di-edit. 
d. Data Manipulation dan Analysis

Subsistem ini menentukan informasi-informasi yang dapat dihasilkan oleh SIG lain, subsistem ini juga melakukan manipulasi dan pemodelan data untuk menghasilkan informasi yang diharapkan. Menurut Eddy Prahasta subsistem SIG bisa dilihat pada Gambar 1.

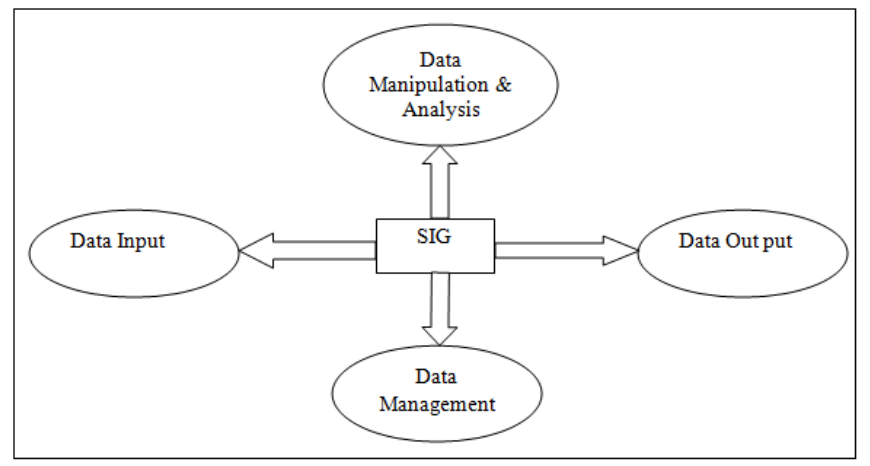

Gambar 1 Subsistem-subsistem SIG

\section{Metode Penelitian}

\subsection{Subjek Penelitian}

Subyek penelitian yang akan dibahas pada tugas akhir ini adalah "Sistem Informasi Geografis Objek Wisata Kabupaten Lombok Barat Berbasis Web". Sehingga dapat digunakan sebagai media bantu untuk memberikan informasi pariwisata di Kabupaten Lombok Barat secara interaktif, cepat dan sudah. Materi yang digunkan dalam penelitian ini adalah informasi yang diperoleh dari Dinas Kebudayaan dan Pariwisata Kabupaten Lombok Barat.

\subsection{Alat Penelitian}

Alat yang digunakan dalam penelitian yaitu perangkat keras (hardware) dan perangkat lunak (software).

1. Perangkat Keras (Hardware) dengan spesifikasi sebagai berikut:
a. Asus
b. Processor Intel Core i3
c. RAM 2GB DDR3.
d. Harddisk 500GB.
e. Printer EPSON Stylus T13x.
f. Modem SMARTFREN EC1261-2.

2. Perangkat Lunak (Software) dengan spesifikasi sebagai berikut:
a. Sistem Operasi Windows 7 Enterprise.
b. Browser Google Chorome 19.0 dan Mozila Firefox 12.0.
c. Microsoft Office 2007.
d. Notepad ++ untuk membuat dan mengedit script pemrograman.
e. Macromedia Dreamweaver 8.
f. Adobe Photoshop CS3 untuk desain header web.
g. Codelgniter sebagai framework website.
h. Power Designer 6.0. 
i. PHP dan MySQL.

\subsection{Metode Pengumpulan Data}

Cara pengumpulan data dilakukan melalui sebuah penelitian. Dalam melakukan penelitian akan dilakukan cara-cara pengumpulan data sebagai berikut:

\section{Metode Studi Pustaka}

Studi Pustaka adalah metode pengumpulan data yang dilakukan dengan mencari, mengkaji informasi, atau data pada literature yang berhubungan dengan subjek penelitian tentang SIG, baik dari artikel, brosur, pamflet, dan penelitian terdahulu maupun dari website. Serta mempelajari dan menganalisa literature yang berhubungan dengan pariwisata di Kabupaten Lombok Barat.

\section{Metode Wawancara}

Merupakan metode yang dilakukan dengan cara tanya jawab atau wawancara pada orang yang mempunyai kapasitas dan informasi yang dibutuhkan dalam pelaksanaan penelitian yang dalam hal ini adalah Bapak H. Ilham S.Pd.,M.P.d. Selaku kepala Dinas Kebudayaan dan Pariwisata Kabupaten Lombok Barat.

\section{Metode Observasi}

Metode Observasi ini digunakan untuk mempelajari dan mengetahui secara langsung objek yang diteliti. Pengumpulan data ini dilakukan dengan cara langsung mengamati permasalahan mengenai objek wisata di Kabupaten Lombok Barat.

\section{Hasil Dan Pembahasan}

Implementasi SIG objek wisata di Kabupaten Lombok Barat adalah sebagai berikut:

\subsection{Tampilan Halaman Utama}
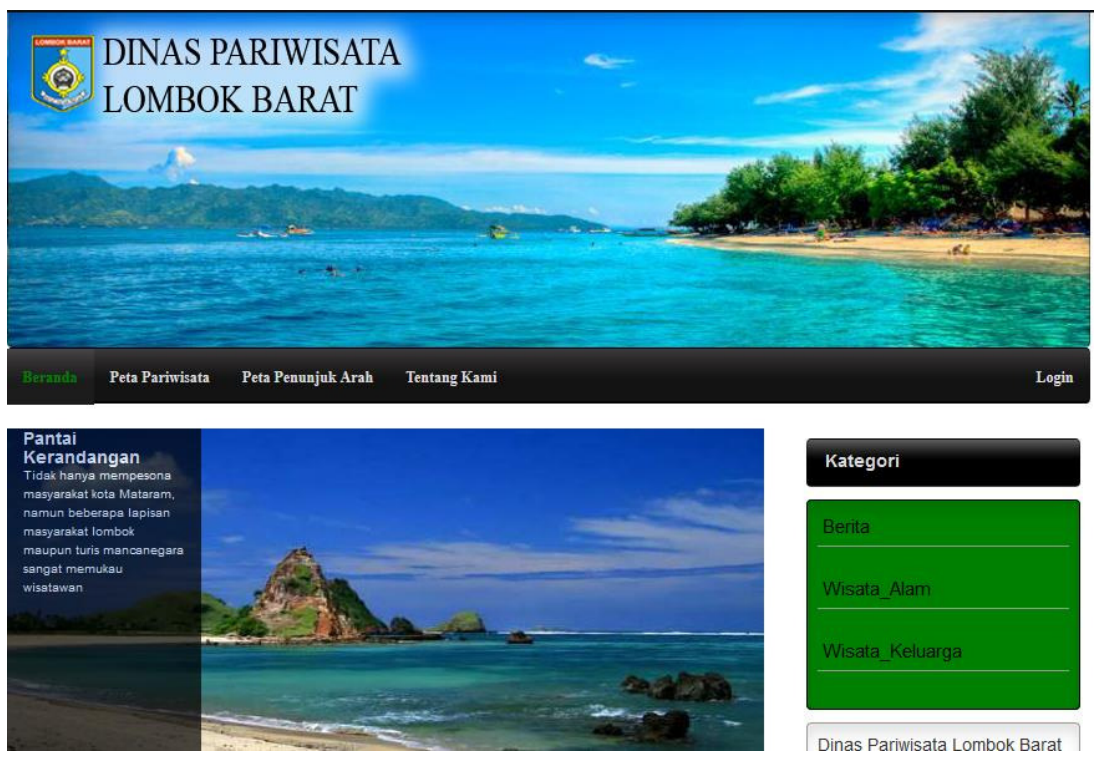

Gambar 2 Halaman Utama

Gambar 2 merupakan Halaman index atau halaman utama merupakan halaman pembuka dan pertama kali muncul ketika user mengunjungi situs website ini. 


\subsection{Halaman Info Lokasi Pariwisata}

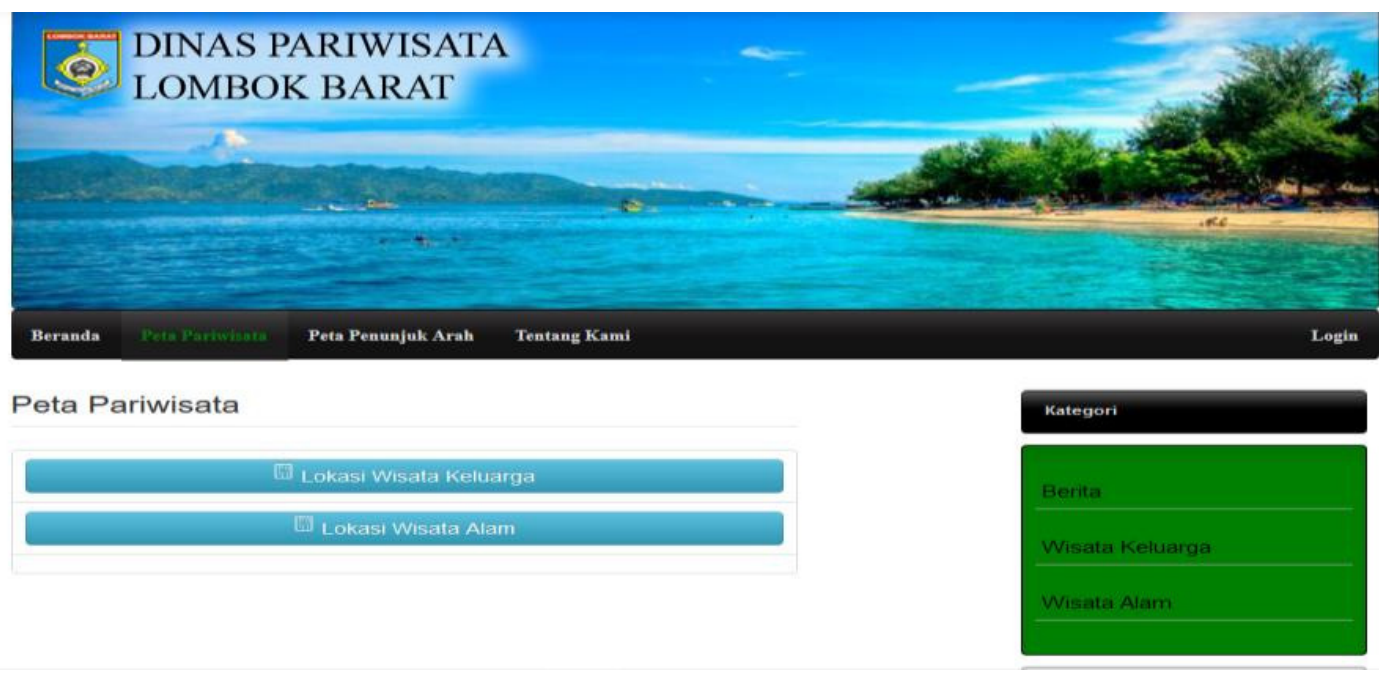

Gambar 3 Halaman Info Lokasi

Gambar 3 merupakan Halaman info lokasi merupakan halaman informasi lokasi pariwisata ketika user mengklik menu info lokasi, terdapat keterangan di setiap marker. Marker warna merah menunjukan bahwa itu tempat wisata alam, marker warna biru menunjukkan lokasi wisata keluarga.

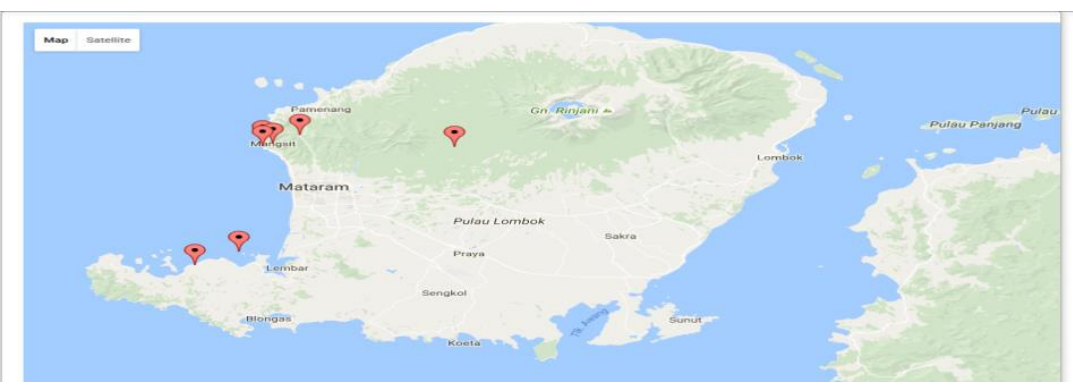

Gambar 4 Lokasi Wisata Alam

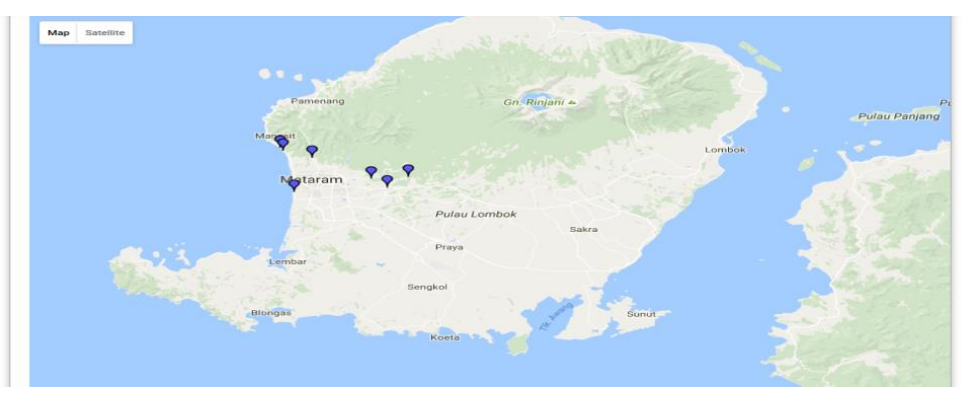

Gambar 5 Lokasi Wisata Keluarga 


\subsection{Halaman Profil Objek Wisata}
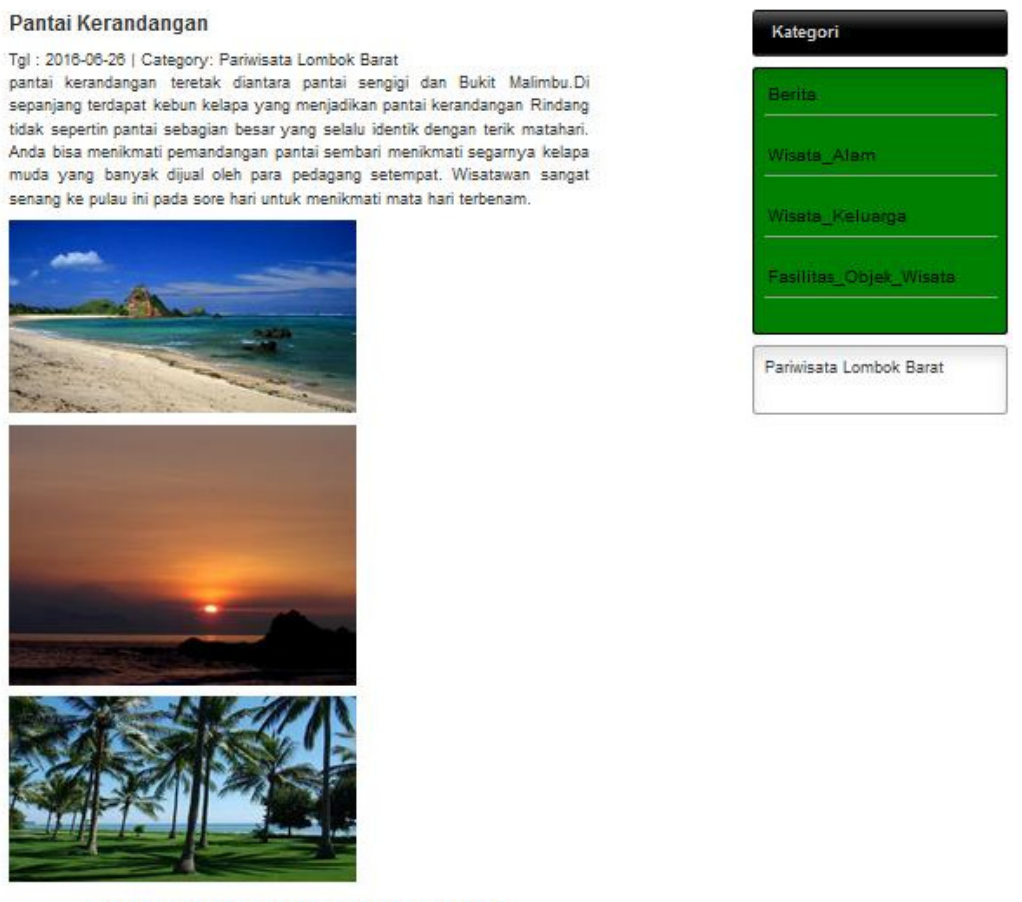

Gambar 6 Halaman Profil Objek Wista

Gambar 6 merupakan halaman informasi wisata, ketika user mengklik menu jenis pariwisata, terdapat informasi mengenai objek wisata dan ketika user memilih wisata yang diinginkan maka akan muncul profil objek wisata.

\subsection{Pengujian Sistem}

Pengujian sistem ini menggunakan pengujian Black Box Test yaitu orang yang mengerti tentang sistem informasi, dalam hal ini dilakukan oleh Muhammad Zikri., S.S, selaku Staff Dinas Kebudayaa Dan Pariwisata Kabupaten Lombok Barat. Alpha test, yaitu: User yang melakukan test dalam metode ini adalah pegawai Dinas Pariwisata, masyarakat atau wisatawan dengan komposisi 3 pegawai Dinas Pariwisata, 4 Masyarakat.

\section{Kesimpulan}

Berdasarkan analisa yang telah dilakukan pada Sistem Informasi Geografis Objek Wisata kabupaten Lombok Barat Berbasis Web pada bab sebelumnya maka dapat diambil kesimpulan sebagai berikut:

1. Sistem informasi geografis ini diharapkan mampu menjadi media yang efektif untuk pengolahan data mengenai objek wisata di kabupaten Lombok barat.

2. Sistem informasi geografis ini diharapkan mampu menjadi media yang efektif dalam rangka memberikan informasi mengenai objek-objek wisata di kabupaten Lombok barat ke masyarakat luas.

3. Sistem informasi geografis ini diharapkan mampu memberikan gambaran mengenai letakletak objek wisata dan dapat menjadi acuan para wisatawan dalam berkunjung ke tempat wisata berdasarkan kategori.

4. Berdasarkan hasil pengujian black box test yang telah dilakukan oleh Muhammad Zikri, S.S bahwa aplikasi Sistem Informasi Geografis Objek Wisata Kabupaten Lombok Barat Berbasis Web layak untuk dipublikasikan dengan hasil pengujian black box test 10/10 x $100 \%=100 \%$. Aplikasi ini selain mampu memberikan layanan informasi kepada wisatawan 
maupun masyarakat tentang lokasi objek wisata, informasi tentang petunjuk arah dan rute yang akan dilalui. Pengujian alfa test menunjukan bahwa aplikasi Sistem Information Geografis Objek Wisata Kabupaten Lombok Barat Berbasis Web yang dilakukan oleh pegawai Dinas Pariwisata dan masyarakat, layak digunakan sebagai media untuk membantu wisatawan mencari lokasi objek wisata yang ada di Kabupaten Lombok Barat dengan hasil pengujian alfa test $52,38 \%$.

\section{Daftar Pustaka}

[1] M. Yolan, "Sistem informasi pariwisata propinsi nangroe aceh darussalam berbasis web," $J$. Fak. Ilmu Komput. Univ. Borobudur, vol. 2939, 2014.

[2] P. Lestari et al., "Sistem Informasi Geografis Berbasis Web Untuk Pemetaan Pariwisata Kabupaten Kebumen,” vol. 11, no. 1, pp. 45-57, 2013.

[3] F. Fajrizal, M. A. Hasan, and Y. Yunefri, "Aplikasi Sistem Informasi Geografis Kelurahan Sei. Mempura Berbasis Web,” Digit. Zo. J. Teknol. Inf. dan Komun., vol. 6, no. 2, 2015.

[4] E. Prahasta, "Konsep-konsep dasar sistem informasi geografis," Inform. Bandung, 2001.

[5] E. Prahasta, "Sistem Informasi Geografis: Tutorial ArcView,” Inform. Bandung, 2002. 